\title{
Roman Bartnicki, Jezus w drodze do śmierci i zmartwychwstania. Komentarz do Ewangelii Marka 8,27-16,20. II. Mk 14,1-16,20 (Warszawa: Instytut Papieża Jana Pawła II 2019). Ss. 478. PLN 49. ISBN 978-83-65198-60-0
}

\section{STEFAN SZYMIK}

Katolicki Uniwersytet Lubelski Jana Pawła II stesz@kul.pl, ORCID: 0000-0001-9544-2976

Ksiądz prof. dr hab. Roman Bartnicki jest postacią dobrze znaną nie tylko w środowisku biblijnym. Kapłan archidiecezji warszawskiej, profesor nauk teologicznych, były rektor ATK (1996-1999) i UKSW (1999-2005), członek polskich i zagranicznych stowarzyszeń naukowych, a przede wszystkim biblista i teolog, znany jest przede wszystkim jako autor licznych książek i artykułów naukowych, z których nieprzypadkowo na osobne wyróżnienie zasługują tutaj opracowania z zakresu metodologii biblijnej. Obok bowiem Ewangelii synoptycznych to właśnie hermeneutyka i metodologia biblijna znajdują się w centrum jego naukowych zainteresowań. Wyraźne ślady tych prac badawczych noszą również obie części opublikowanego niedawno komentarza do Ewangelii według św. Marka, by być precyzyjnym - jej drugiej części (Mk 8,27-16,20).

Recenzowana publikacja liczy 478 stron i jest kolejną częścią komentarza biblijnego, tym razem do Markowego opowiadania o męce, śmierci i zmartwychwstaniu Jezusa (Mk 14,1-16,20)1. Książkę otwierają elementy formalne: skrócony (s. 5-6) i pełny spis treści (s. 7-14), życzliwe słowo ks. abp. Stanisława Gądeckiego (s. 15) i autorska przedmowa, w której autor wyjaśnia najważniejsze założenia publikowanego komentarza. Jest to jakby małe kompendium współczesnych zasad interpretacji historycznej i teologicznej tekstów biblijnych, łącznie z ich aktualizacją, jakie stosuje on w publikowanym opracowaniu (s. 17-20). Zakończenie wstępnej, formalnej części komentarza zawiera obszerny wykaz skrótów (s. 21-31) i przyjęte zasady transliteracji tekstów oryginalnych (s. 32-33).

W punkcie pierwszym opracowania (5.1. „Wprowadzenie do opowiadania o męce”, s. 36-63) autor dyskutuje ogólne zagadnienia przed-markowej historii męki i śmierci Jezusa, związane z formowaniem się (źródła), przekazem apostolskim (tra-

1 Por. wcześniej publikowany komentarz: R. Bartnicki, Jezus $w$ drodze do śmierci i zmartwychwstania. Komentarz do Ewangelii Marka 8,27-16,20. I. Mk 8,27-13,37 (Warszawa: Instytut Papieża Jana Pawła II 2018). 
dycja) i włączeniem przez Marka do ewangelii (redakcja); omawia również możliwość literackiej rekonstrukcji tego przed-markowego opowiadania i jego antyczne, możliwe analogie literackie. W tym krótkim, chociaż ważnym i ciekawym wprowadzeniu zastanawia jedynie obecność punktu 5.1.5, poświęconego Ewangeliom jako biografiom (s. 48-51). Z jednej strony przerywa to bieg wywodów poświęconych literackiej i historycznej problematyce opowiadania o męce i śmierci Jezusa, z drugiej - rodzi wątpliwość, czy materiał podejmujący kwestię literackiego gatunku Ewangelii nie powinien raczej znaleźć się w „Wiadomościach wstępnych”, którymi autor poprzedził pierwszą część komentarza do drugiej Ewangelii (punkt 1.1)2.

Następne punkty komentarza (5.2-17) odnoszą się sukcesywnie do kolejnych odsłon opowiadania o męce i śmierci Jezusa, począwszy od spisku przeciwko Jezusowi i namaszczenia w Betanii (Mk 14,1-11) poprzez wydarzenia w Wieczerniku, Getsemani i przed Sanhedrynem aż po śmierć krzyżową, pogrzeb, zmartwychwstanie Jezusa (Mk 16,1-8) i także wniebowstąpienie (Mk 16,9-20 - tzw. dłuższe zakończenie Ewangelii). Czynnikiem łączącym tych szesnaście punktów jest nie tylko ta sama treść, tj. męka i krzyżowa śmierć Jezusa, ale także ich układ formalny, w którym stale pojawiają się trzy składniki komentarza: zagadnienia literacko-historyczne, egzegeza i kerygmat. To samo podejście do tekstu biblijnego znajdziemy w serii najnowszych komentarzy biblijnych wydawanych przez częstochowską Edycję Świętego Pawła. Nie powinno to jednak dziwić czytelnika, jeśli pamięta o swoistej „prehistorii” recenzowanej publikacji, o czym jednak nie ma potrzeby pisać, gdyż zrobili to już recenzenci pierwszej części komentarza (do Mk 8,27-13,37)3.

Oryginalnym rysem recenzowanej publikacji jest wszechstronne omówienie przez autora kwestii literacko-historycznych analizowanego tekstu biblijnego. Wprawdzie w podobnych komentarzach Edycji Świętego Pawła zagadnienie to również zostało uwzględnione, jednak propozycja Bartnickiego daleko przekracza analogiczne opracowania. Omawiając problematykę literacką i historyczną perykop Markowej Ewangelii, autor posługuje się zawsze tym samym, prawie szkolnym schematem badawczym tekstu biblijnego: delimitacja, kontekst, analiza narracji, struktura, gatunek literacki, historia tradycji, historia redakcji; czasami klisza ta zostaje uzupełniona o inne elementy formalne (np. s. 289-302). Interesujące, iż schemat ten nie zawsze jest odnoszony konsekwentnie do każdej perykopy, a czasem jego elementy omawiane są jedynie wybiórczo, co można by uznać za pewną niekonsekwencję. Jednak w opinii recenzenta było to świadome postępowanie autora, świadczące o jego wielkim doświadczeniu egzegetycznym i praktycznym. Egzegeta ma wprawdzie wypracowany warsztat naukowy, jednak to tekst biblijny i jego forma mają zawsze

Bartnicki, Jezus w drodze do śmierci, I, zwł. 40-53.

Zob. W. Chrostowski (Collectanea Theologica 88/4 [2018] 225-229); J. Lemański (Studia Koszalińsko-Kotobrzeskie 26 [2019] 367-371); M. Rosik (The Biblical Annals 9/3 [2019] 591-596); także R. Krawczyk (Teologiczne Studia Siedleckie 15 [2018] 342-343). 
decydujące znaczenie w procesie komentowania i stosowania narzędzi badawczych. Praca egzegety to praca twórcza, to również wybór i kreacja. Warto, aby młodsze pokolenia polskich biblistów pamiętały o tym aspekcie badań biblijnych.

Drugim ważnym elementem recenzowanego komentarza są liczne, choć czasem niezbyt obszerne ekskursy, których łącznie jest sześć: „Geneza święta Paschy” (s. 150-151), „Rytuał Paschy w czasach Chrystusa” (s. 152-155), „Liturgie, obrządki i ryty” (s. 156-160), „Namiestnicy rzymscy. Poncjusz Piłat” (s. 280-281), „Cierpienie i gwałtowna śmierć w hellenistycznych i łacińskich biografiach” (s. 325-326), „Współczesne badania poświęcone starożytnym ukrzyżowaniom” (s. 327-331). Tytuły ekskursów wskazują wprost na ich uzupełniający, komplementarny w stosunku do bieżącego komentarza charakter. Równocześnie jednak warto zaznaczyć, iż Bartnicki przekracza komentowane treści, zamieszczając w ekskursach informacje z zakresu historii oddziaływania tekstu biblijnego i jego twórczej recepcji (np. w chrześcijańskiej liturgii). W ten sposób autor przypomina wszystkim o jednej z teologicznych zasad interpretacji tekstu biblijnego - o żywej Tradycji Kościoła (por. KO 12).

Całość publikacji Bartnickiego zamykają dwa aneksy. W pierwszym z nich autor podejmuje niezwykle trudny i delikatny problem ludzkiej odpowiedzialności za śmierć Jezusa (s. 412-418), w drugim - kwestię chronologii opowiadań o męce, w tym datacji Ostatniej Wieczerzy i dnia śmierci oraz przebiegu ostatnich dni życia Jezusa - wielkiego tygodnia (s. 419-429). Na końcu publikacji została dołączona obszerna bibliografia konsultowana przez autora podczas pracy nad komentarzem (s. 430-476).

Pewne uwagi pozytywne i czasem krytyczne na temat recenzowanej publikacji zostały dołączone już wyżej w trakcie jej prezentacji. Dalsze, bardziej szczegółowe i krytyczne omówienie mija się z celem niniejszej recenzji, gdyż należałoby poruszyć liczne, szczegółowe zagadnienia dotyczące męki i śmierci Jezusa. Odnotować jednak należy, iż recenzentowi czasem brak u Bartnickiego wyraźnego i jednoznacznego stanowiska w poszczególnych kwestiach. Niekiedy autor ograniczył się jedynie do naświetlenia problemu i podania wiodących opinii. Natomiast $\mathrm{z}$ satysfakcją recenzent zwraca uwagę czytelnika na liczne pozytywne elementy obecne w każdej części komentarza, w tym na wyczerpujące przedstawienie kwestii tzw. dłuższego zakończenia drugiej Ewangelii Marka (s. 382-411). Na osobne podkreślenie zasługuje staranne przygotowanie recenzowanej publikacji do druku przez Instytut Papieża Jana Pawła II. Z pewnością obie części komentarza do Ewangelii według św. Marka (Mk 8,27-13,37; 14,1-16,20), których autorem jest ks. prof. Roman Bartnicki, przyczynią się do pogłębienia wiedzy biblijnej i pełniejszej znajomości drugiej Ewangelii kanonicznej, w tym w szczególności męki i śmierci Jezusa - Mesjasza i Syna Bożego. 
